\title{
Seeing the Other Side of the Coin: (Re)Constructing the Normative Flipside to Marx's Sociology*
}

\author{
Samuel A. Butler State University of New York at Stony Brook
}

\begin{abstract}
Résumé
Le présent article constate, malgré les protestations de Marx à l'encontre, l'existence d'un noyau d'éthique dans sa critique du capitalisme. C'est une démonstration que je m'efforce d'étayer par des points saillants de la critique effectuée par Marx. Ceci fait, je passe à une discussion de la conception que Marx avait de la nature humaine comme étant typiquement frustrée dans des sociétés précommunistes. Cette frustration constitue la base d'une préférence morale pour le communisme. Après avoir envisagé brièvement l'argument selon lequel cette préférence morale se réduirait à une idéologie, je conclus avec le cœur normatif de la question. Je souligne alors les principales similitudes entre le travail de Marx et le projet éthique d'Aristote, dans la mesure où l'un comme l'autre comprend une description intuitive de la belle vie et une analyse des conditions préalables à son obtention. Saisir cette similitude, c'est esquisser une compréhension du revers normatif du projet intellectuel de Marx.
\end{abstract}

\begin{abstract}
This paper argues that, Marx's insistences notwithstanding, there is an ethical core to Marx's critique of capitalism. I attempt to establish this claim through presenting salient points of Marx's critique. From this basis, I move on to discuss Marx's conception of human nature and the way in which it is typically frustrated under pre-communist societies. This frustration is the basis for a moral preference for communism. After pausing briefly to consider the possible criticism that this moral preference is mere ideology, I conclude with the normative heart of the matter. This is addressed by underscoring principal similarities between Marx's work and Aristotle's ethical project, insofar as each comprehends an intuitive description of the good life and an analysis of the prerequisites for obtaining it. A grasp of this similarity opens the door to understanding the normative flip side of Marx's intellectual project.
\end{abstract}

* This paper has benefited enormously from the insightful criticism of two anonymous referees from Socialist Studies. 
-Heads.

- There is an art to the building up of suspense.

-Heads.

-Though it can be done by luck alone. [...] A weaker man might be moved to reexamine his faith, if in nothing else at least in the law of probability (Stoppard, 1967: 12).

\section{Introduction}

Every so often, one will hear a historian claim that all the debates to be had in philosophy have already been had, usually during whatever period that historian studies. Even more often, one will observe a debate rehashing old material, sometimes with positions markedly less thought out or interestingly developed than the first time around. Almost constantly, events in the real world make one wish that the scholar's life was not such an unusual privilege in our society.

I am thankfully not at all unusual in combining work as a scholar and an activist. Most days the two roles seem to complement each other; on good days they are indistinguishable. I like to think that my scholarship informs my activism as my activism justifies my scholarship. I hope to be able to glean from intellectual history insights that will carry my activism further and make it more likely to succeed. Insofar as this occurs, I would argue that my intellectual work has some claim to the social resources sacrificed to make it possible.

I have cut my activist teeth in a time and place where the left finds itself mired in considerable turmoil. The most inexperienced activist can rattle off the names of dozens of leftist groups and organizations, organizations who join forces with regrettable infrequency. Communism and Marxism were declared dead about the time I completed my first decade of existence. I did not much notice at the time.

As the left in the United States has distanced itself from Marx, our politics have become overrun with a warmed-over humanism which is facile, ungrounded, unscientific and largely ineffectual. A moderately plausible case can be made that the former has led in some sense to the latter. Whatever the causes of the shifts, it cannot be denied that we march too often these days to the tune of the regrettable mantra, 'Shame! Shame! Shame!'

Something must be done. Not only do we know nothing more about empire when we know that it contradicts la justice éternelle, but we can also do nothing more about empire with that information. The thumb of moral disapprobation has flipped the coin 
of dissent more times than I care to imagine. I am no longer surprised when the coin comes up 'heads' once again; I am only surprised when we simply redouble our efforts with the same tactics. We are coming close to disproving the old adage about a multitude of monkeys and typewriters, showing just how fond of routine monkeys can becomeeven monkeys with typewriters.

It is in the spirit of all of this that I want to drudge up an old debate in Marxism. We are stuck in our present; perhaps we can learn from our past. In the late 1970s and early 1980s a debate was carried out in Marxist philosophy over the question of the place of morality in Marx's critique of capitalism. The debate is fascinating for its wide scope, large number of participants and continued relevance for the state of current action.

At the same time, the debate is limited by the concerns of the time, the concerns of analytic Marxism and a desire on behalf of the participants to distance themselves from the anti-humanism of Louis Althusser. Returning to the debate now permits the questions to be addressed without the baggage of that Anglo-Franco tiff. Recent work in virtue ethics makes is possible to see even more Aristotle in Marx, this time in an ethical realm. The ability to do this is the ability to provide an account of Marx which leaves his overall project much more unified than an explanation in terms of justice, and the ability to talk about our political struggles in language which goes beyond the dead end of simple opposition.

The argument is that, in spite of Marx's general objections to the incorporation of normative elements into a sociological argument, there is an axiomatic preference for a post-capitalist society implicit in Marx's critique of capitalism itself. The preference is not an adjunct to Marx's history or economics, but rather a full (if submerged) partner. Put another way, Marx's critique of capitalism assumes that humans have moral grounds for preferring communism to capitalism.

Put briefly, the reasons for the preference are this: Marx's history of the development of productive capabilities exposes a distinction between two sorts of labour - socially necessary labour, which provides for the material needs of a society, and the labour of individuation, which is the work of self-expression and self-development humans engage in when freed from material necessity. As production becomes more efficient, the amount of socially necessary labour time decreases, while the amount of time potentially available for the labour of individuation increases. This potential is actualized through the proletarian revolution, and its actualization is a moral goal.

In order for this explanation to be made plausible, I begin my discussion with Marx's conception of human nature and the way it is necessarily frustrated under pre- 
communist societies. If human nature is not as Marx argues, or if it is not necessarily frustrated under capitalism, then indeed there can be no moral preference for a postrevolutionary society.

At this point I pause briefly to consider an obvious counter-argument: Marx is famously derogatory in his commentary concerning anything that smells like morality. As a response to this argument, I suggest a reading of 'ideology' such that one can distinguish between moralizing and moral judgment, a reading which admits of a distinction between the sort of account of normative issues I am giving here and the sort given by the pro-moral participants in the earlier debates.

Finally, I flesh out the sort of normative elements suggested by Marx's work, by underscoring principal similarities between Marx's work and Aristotle's ethical project, insofar as each comprehends an intuitive description of the good life and an analysis of the prerequisites for obtaining it. A grasp of this similarity opens the door to understanding the normative flip side of Marx's intellectual project.

\section{Marx's Conception of Human Nature}

An obvious way into the debate on Marx and morality is the door of human nature. While they do not always argue from human nature to moral condemnation, most of the philosophers who argue for the one also argue for the other. In particular, the work of Norman Geras can be characterized in this way, and is remarkable for its extensiveness and generally careful analysis. With respect to human nature, Geras argues that

\section{[...] if diversity in the character of human beings is in large measure set down by Marx to historical variation in their social relations of production, the very fact that they entertain this sort of relations, the fact that they produce and that they have a history, he explains in turn by some of their general and constant, intrinsic, constitutional characteristics; in short by their human nature. This concept is therefore indispensable to his historical theory (1983: 67).}

Indeed it does seem that Marx believed there were certain characteristics of humans which endured across societies and different modes of production, chief amongst which are the tendencies of humans towards society and production as such. Human life is (in part) a material product. Society as a production technology is necessary to attain the level of production required for life. Therefore, humans will in general be involved in production, and that production will be social.

In his early writings, Marx appropriates the Feuerbachian term Gattungswesen to express the fact that humans are social creatures. Such a being represents for Marx the 
'real person', 'objectified', without 'Hegelian abstraction' (1843: 228). It is not that individuals form communities, but rather that communities make individuality possible. 'The human is in the worthiest sense a zoon politikon], not only a social animal, but an animal that can only individuate in society' (1857: 616). Because of the communal needs and nature of humans, they can only develop individual characteristics and differentiation from within the protection and support of a society. This is due to the fact that 'only in community [with others has each] individual the means of developing his gifts in all directions; thus only in society does personal freedom become possible' (1845-6b: 74; interpolation from the editor of the Werke). The process of becoming an individual involves qualitative development of the (in some important sense unique) abilities of the individual. Society thus serves as a necessary condition for both the material and intellectual existence of the individual.

On a macrocosmic level, society also provides for the development of productive forces. The development of productive forces creates a surplus, and this surplus results in the possibility of leisure with which to develop their gifts in other directions. Once a society is able to produce beyond the level sufficient to meet its needs, its members are able to engage in non-necessary labour in order to develop their individuality. The waxing of the productive capabilities of society then provides the opportunity for a larger amount of time spent in something other than socially necessary labour. Because humans are fundamentally productive, Marx thinks this extra time will be spent engaged in the labour of individuation, rather than sitting on the beach.

At a certain stage of development, socialism and communism become possible. Marx describes the conditions of labour under communist society in his Critique of the Gotha Program:

In a higher phase of communist society, after the knavish subjugation of individuals to the division of labor and with it the opposition of intellectual and physical labor has vanished; after labor has become not only the means of life but even the first need of life; after the all-sided development of individuals and their productive forces have grown and all sources of communal riches flow fully [...] only then can society write on its banner: from each according to his capabilities, to each according to his needs! (1875: 21)

Whereas pre-communist societies feature large classes of individuals spending all of their time in socially necessary labour so that a smaller, privileged class can be exempted from such labour, communism features the sharing of both socially necessary labour and leisure. In this situation, the individual is involved in both the production of the individual life as well as the production of individuality - exposing another aspect 
of the distinction between socially necessary labour and the labour of individualization. While this distinction does not map precisely onto the distinction between intellectual and physical labour, there is a great similarity between the two. So long as the two sorts of labour are separated by class boundaries, individuals will engage only (or at least primarily) in the one or the other, creating a distorted view of the sort of things that humans are.

Humans have material needs, which are met by social, material production. Society is the ur-production technique, but it generates in its turn other techniques to continually develop more and more powerful forces of production. As production becomes more efficient, the full manifestation of human essence becomes possible. Freed from the yoke of natural necessity, human productivity and individuality become ends in themselves. Whereas Marx's economic analysis points towards the social form this freedom takes, it is only by teasing out the implicit normative claims that we can understand the nature of this freedom itself, showing how this development results in a life which is fundamentally fulfilling.

Before going further, I want to return briefly to the account that Geras gives of Marx's conception of human nature. The account is, I think, somewhat deflationary in a way that leaves one unsatisfied. Geras reminds us that 'not every conception of human nature is a metaphysical teleology' (1995: 64), and he is right. In his discussion, Geras makes much of a distinction between 'the nature of man [sic]' and 'human nature', where the former is taken to be the set of characteristics describing how people actually are, while the latter describes certain inalterable features of humanity. Taking this impulse further, one can distinguish further between what I will call 'existential' human nature and 'essential' human nature. Attributable to existential human nature are those facts about people which are invariant due to contingent qualities, circumstances or characteristics of humans, while essential human nature is due to necessary qualities, circumstances or characteristics.

It seems that much of the concern about attributing to Marx a conception of human nature is based on a concern about his distance from Feuerbach, his ontological commitments and the importance of the historical development of humanity. With a distinction between existential and essential human nature in hand, however, we can approach the question with much less ontological queasiness. The two characteristics I have suggested as representative of humans according to Marx-gregariousness and labouring-are characteristics which have survived unchanged throughout human history. His predictions about the nature of post-capitalist human society are based on the survival of these characteristics through the transition.

From an existential point of view, this survival doesn't seem to be overly problematic: 
if these characteristics have remained intact through previous shifts in the prevailing mode of prod-uction, there is no obvious reason to believe that they might be radically changed by this one.

Of course the essentialist wants more. From this point of view, the challenge is not just to show that the characteristics are stable, but that they are necessarily so, tied up in some way or other with humanness. I am skeptical about being able to prove this sort of thing, but I am also convinced that proving it is of absolutely no importance to the argument here. Once we are convinced that the characteristics are part of an existential human nature, we have enough to go on. Essentialists can be satisfied, because we don't need to deny that Marx has an essential conception of human nature. At least so far as the question concerning moral claims goes, we don't need to worry about this question.

\section{Ideology and some objections}

So far, so good. We have a story about the changes in labour brought about by the development of production, and we seem to be on our way to the establishment of a moral preference for communism. We have seen that Marx thinks that it's necessary to overcome the division of labour in order to live the good life, and that the division of labour can only be overcome when capitalism is superceded.

Here's one problem: communism will bring about material plentitude, and that plentitude will make it possible to abolish the division of labour. Isn't it true, though, that the ruling class already enjoys that plentitude? Don't they live the good life under capitalism? Is it at all feasible that they should want the revolution? It would seem, for example, that the ruling class could engage in socially necessary labour part-time, reserving a certain amount of leisure for developing individual gifts. Why is this not the good life?

On the level of the ruling class as a whole, Marx can make appeal to history. Capitalists, qua capitalists, don't work. The claim becomes more tendentious at the level of the individual, however. Engels, for example, presumably could have stopped giving all of his money to support revolutionaries and used it to take up living the good life. He could have given himself a part-time job sweeping floors in his textile factories, and done painting or pushpin on his days off. Why is this not a satisfactory state of affairs?

The ruling class controls the means of production, not the mode of production itself. Capitalism is not an instance of production lying in the rational control of a few, but rather of uncontrolled production. Part of the reason it is uncontrolled is because even the ruling class fails to understand its own social reality. Instead of an accurate, 
scientific explanation, social realities are explained by a variety of ideas (scientific, political, normative, \&c.) that stabilize a mode of production by obfuscating the social realities at work. On Marx's analysis, all members of society are under the sway of this sort of ideology. This obfuscation keeps the ruling class from an understanding of capitalism, making it impossible for even it to exploit capitalism to produce a fulfilling existence. Ideology makes production possible by politically justifying or delaying the recognition of exploitation in society. Ideology is an effective social mechanism insofar as it allows the ruling class to maintain a mode of production.

Ideological explanations combine descriptive and normative content. They advance propositions about the world (e.g., 'the natural state of humans is one of free exchange', 'anyone who works hard can make a good living') as well as a normative judgement indicating that these features of the social world are acceptable or desirable.

Untangling the descriptive and normative aspects of ideology is a complex task, further complicated by Marx's silence on the matter. It is clear that normative claims sometimes play an ideological role. It is equally clear that not all normative claims play an ideological role. In order for a normative claim to be ideological, it must be able to actually play a social role. The capitalist prohibition on theft does. The Categorical Imperative doesn't (at least not explicitly). The Categorical Imperative (and other claims whose explicit use is limited to a small part of the population) is not properly the province of a sociologist attempting to understand society at large. Marx is interested in normative claims which specifically have some social force. Many moral claims fail to be ideological because they lack the necessary social force to serve as a stabilizing mechanism to a mode of production. In these cases, the question of whether they obfuscate underlying social reality simply does not present itself.

While Marx does not make the claim that all morality is ideological, he does make the somewhat weaker claim that all morality is 'obsolete verbal rubbish' (1875: 22). If a normative claim has social force, then it gains that force because of its agreement, its 'fit' (Allen Wood's term) with the prevailing mode of production (1972: 15). If it lacks this fit (if it tends to condemn the mode of production), it will also lack social force. If it has no social force, then it is useless to a revolutionary. Finally, a revolutionary will have no recourse to alternative moral paradigms, because condemnation based in an external system of norms carries no weight, political, normative or otherwise. To condemn a mode of production by such a technique is to beg the question, in a sense.

Because they will be either ideological or question-begging in this sense, normative judgements can play no role in a revolutionary program. It might be the case that accepted norms will condemn individuals from the ruling class from time to time, but no norms are 
both powerful and radical enough to undermine the entire social and class structure. A response to this objection is a bit harder to come by, and requires that I provide a final formulation of the preference for the overthrow of capitalism. If anything is going to validly condemn a mode of production, it would have to be non-ideological and nonquestion begging. It must arise from within the movement of history - it must be the normative flipside of Capital.

\section{The Normative Content}

There are scattered instances where Marx seems almost willing to explicitly endorse the idea that the predicted outcomes of the revolution of the proletariat have moral value. In The Holy Family, he and Engels write,

If enlightened interest is the principle of all morality, then it is a question of the private interest of a person coming together with the human interest. [...] If the human is shaped by his surroundings, then one must shape his surroundings into a human form (1845-6a: 138).

The process of the private interest of a person coming together with the human interest is none other than the dissolution of the apparent antagonism between the individual and society. The full development of the individual involves both socially necessary labour and the labour of individuation. These labours change the world in which the individual lives, becoming media of individual expression against the backdrop of the world.

Rationally controlled production is a necessary condition for this sort of two-sided labour. Communism represents the free association of producers who rationally control production. The rational control of production necessitates an accurate understanding of social reality. A society whose members possess an accurate understanding of the workings of society is a society without ideology.

Freed from ideological sway, rational producers are able to understand their needs as material beings and human producers. Their labour meets their needs both in terms of the process of performing it as well as in its material output. The society secures for itself the good life of socially necessary and individuating labour, free from the antagonism that marks previous social arrangements.

Marx doesn't argue that we should want this sort of labour; he thinks we intuitively and historically do. In this way, his démarche is formally not unlike that of Aristotle, in the Nicomachean Ethics (1952). I take the relevant similarities to be these: Aristotle begins by describing what it is to be a eudaimon - a successful, excellent person. He describes eudaimonia as resulting from the exhibition of virtues and moral luck. He then asks 
whether eudaimonia is 'one of the things we praise or rather one of the things we honor'. It turns out that we praise those things which are under an individual's control, and honor those things which are (partially) beyond control. Virtues, being under the control of the moral agent, are praised. Success, involving moral luck in addition to virtue, is the proper object of honor, but not praise. Aristotle describes a sort of life he thinks his reader will find intuitively appealing, and then sets about working out a set of virtues to be perfected in order to live that morally laudable life.

Rearranging the presentation of Marx's project, the similarity with that of Aristotle becomes quite apparent. To put the normative content first, Marx can be read as first describing the intuitive components of the good life. He then provides an economic argument to show how the continued existence of capitalism keeps the good life out of the reach of at least most of us. As a matter of economic necessity, capitalism can not generally provide the good life. There is, however, good news. While capitalism can't provide for the good life, it does lay the groundwork for an economic system which can. The path to this good life is revolutionary. To live in circumstances where this revolution is possible is to be morally lucky. Under such circumstances, to work to bring about the revolution is to make the morally laudable life possible. In order to have a perfected society, it is necessary to have a movement for that society in addition to the luck of being in an economic situation which makes it possible for the movement to succeed.

Wood (1972) is thus correct, so far as he goes. To work for the revolution is not to carry out the good, but to prepare the conditions for the good life. To carry out the revolution is ' $a$ thing honored and perfect', to use the Aristotelian language. There might be nothing intrinsically morally good about the immediate results of the revolution (further development of productive forces, resultant leisure, rationally controlled production), but the revolution is necessary to achieve the intrinsic good of the good life.

Appreciating this aspect of the project is to appreciate why the sort of reading offered by Geras $(1983 ; 1985)$ is unacceptable - if we are only concerned with the distribution of certain goods, then there is no particular reason why capitalism per se is objectionable. We might just as well get along quite fine with a sort of compassionate capitalism which took due care to redistribute privately earned gains. Geras might be right about this, and the possibility that he might be right is cause enough to read and take seriously his work as much as it is cause to read and take seriously the work of Eduard Bernstein (1899). It is not, however, cause to think that their positions are compatible with that of Marx.

Returning, finally, to our enlightened bourgeois individual, we see why it is doubtful that a member of the bourgeoisie would pursue fulfillment through part-time jobs. To 'work 
oneself up to a theoretical understanding of the entire historical movement' is to understand the historical chain of conditions and the possibilities it holds (Marx \& Engels, 1847-8: 472). To understand the entire historical movement is to understand what a pale imitation of the good life such an arrangement would be. While the content of the labour performed might be similar, it would be performed against community, in isolation from both the bourgeoisie and the ruling class. To pursue such an arrangement is to privilege the labour component of the good life over the communal character of it. It is to fail to understand Marx's conception.

The normative and descriptive sides of Marx's project are indispensable to each other. Humans begin in a primitive state, a state where the sense of individual/societal antagonism is lessened, but where there is a marked paucity of opportunity to perform the labour of individuation. Productive forces develop in such a way that humans subjugate themselves to the division of labour and cease to understand the functioning of the society they created for their survival. The communist revolution represents the taking in hand of their rationality and the workings of their society. To work for the rational control of society is to work for fulfillment and the morally laudable life. Capitalism is a barrier to the morally laudable life, so that action undertaken to overcome it lays the groundwork for the good life. To understand this is to stop flipping the coin and to choose sides with history. 


\section{REFERENCES}

Aristotle. 1952. Eudemian Ethics. H. Rackham (trans.). Cambridge: Harvard University Press.

Aristotle. 1926. Nicomachean Ethics. H. Rackham (trans.). New York: G.P. Putnam's Sons.

Bernstein, E. 1899. Die Voraussetzungen des Sozialismus und die Aufgaben der Sozialdemokratie. Stuttgart: Dietz.

Engels, F. 1877-8. Herrn Eugen Dühring's Umwälzung der Wissenschaft (Anti-Dühring). MarxEngels Werke, Vol. XX. Berlin: Dietz.

Geras, N. 1995. Solidarity in the Conversation of Humankind. New York: Verso.

Geras, N. 1986. "The Controversy about Marx and Justice.” In Literature of Revolution: Essays on Marxism. London: Verso, pp. 3-58.

Geras, N. 1983. Marx and Human Nature: Refutation of a Legend. London: Verso.

Gould, C.C. 1978. Marx's Social Ontology: Individuality and Community in Marx's Theory of Social Reality. Cambridge, MA: MIT.

Marx, K. 1894. Kapital III. Marx-Engels Werke, Vol. XXV. Berlin: Dietz.

Marx, K. 1875. Kritik der Gothaer Programme. Marx-Engels Werke, Vol. XIX. Berlin: Dietz, Berlin.

Marx, K. 1846. "Lettre à Annenkov". Euvres, Vol. I. Tours: Gallimard.

Marx, K. 1857. Einleitung zur Kritik der Politischen Okonomie. Marx-Engels Werke, Vol. XIII. Berlin: Dietz.

Marx, K. 1843. Kritik der Hegelschen Staatsrecht. Marx-Engels Werke, Vol. I. Berlin: Dietz.

Marx, K. \& F. Engels. 1847-8. Manifest der Kommunistischen Partei. Marx-Engels Werke, Vol. IV. Berlin: Dietz.

Marx, K. \& F. Engels. 1845-6a. Die Heilige Familie, oder Kritik der Kritischen Kritik. Marx-Engels Werke, Vol. II. Berlin: Dietz.

Marx, K. \& F. Engels. 1845-6b. Die Deutsche Ideologie. Marx-Engels Werke, Vol. III. Berlin: Dietz.

Miller, R.W. 1981. "Marx and Aristotle." In Marx and Morality. K. Nielson and S. Patten (eds.). Guelph: Canadian Association for Publishing in Philosophy, pp. 323-52.

Stoppard, T. 1967. Rosencrantz and Guildenstern Are Dead. New York: Grove Press.

van Zuylen, M. 2003. 'The Importance of Being Lazy'. Cabinet, 11, 30-33.

Wood, A. 1972. 'The Marxian Critique of Justice'. In Marx, Justice and History. M. Cohen, T. Nagel and T. Scalon, (eds.). Princeton: Princeton University Press. pp. 3-41. 